\title{
Levels of Students' Problem-Solving Skills and Creative Attitudes in Project-Based Learning
}

\author{
Eunjoo $\mathrm{Oh}^{1}$ \\ ${ }^{1}$ Professor, Department of Liberal Studies, Kyungil University, Korea, eoh1@ @anmail.net
}

\begin{abstract}
This study attempted to examine the levels of problem-solving skills and creative attitudes of college students and find out the effective ways of improving project-based learning environments. To achieve the study goals, a survey method was conducted to 144 students with three classes who enrolled in the same project-based class. The participants consist of three different classes with different academic areas such as nursing, engineering major, and students in the social science departments. They took the same project-based class with the same instructor. Students filled out and submitted the survey form on the research website The results of the study showed that students have low levels of problemsolving skills and creative attitudes. In particular, diverse thinking, planning ability, and modifying information categories were relatively lower than other categories. In the case of diverse thinking and decision-making areas, there was a statistical difference by gender. The female students showed stronger diverse thinking and decision-making abilities than the male students. Based on the study results, effective ways of improving students' competencies needed in project-based learning are suggested.
\end{abstract}

Keywords: Problem-solving, Creative Attitudes, Creativity, Project-based Learning

\section{Introduction}

\subsection{Background}

People encounter decision-making situations in their everyday lives. Decision-making is a thinking process that requires problem-solving abilities based on understanding the various perspectives of circumstances[1]. Problem-solving skills are essential skills in every field, and they can be cultivated through training and education. In particular, problem-solving skills would be effectively developed when learning is in real problem-solving situations. Educators long attempted to present ways of strengthening the students' abilities to solve problems through various teaching strategies and methods[2-4]. Higher education institutions provide students with multiple classes that enrich students' knowledge and practical skills for adjusting to real-world situations. Project-based learning is one of the teaching method that makes students actively engage in learning by thinking and sharing ideas and knowledge with each other[2-4]. Students often become passive learners in traditional lecture classes, lacking opportunities to think and communicate with others. For successful learning, students need to engage in problem-solving activities and share creative ideas through the project.

Project-based learning is a way to improve learning outcomes by breaking traditional learning methods[2]. In this learning environment, students work through the learning process to complete a project as a group or independently. Students need creative thinking and problem-solving skills to complete the project. Problem-solving skills are directly related to learning. In particular, problemsolving skills require knowledge for a specific field, and achievement depends on which strategy people

Received: January 04, 2021; $1^{\text {st }}$ Review Result: February 18, 2021; $2^{\text {nd }}$ Review Result: April 07, 2021 Accepted: May 25, 2021 
choose[3][4]. Creativity is a thinking process that makes individuals unique among other people. Creative products are the result of active brain activities. Without creativity, it is difficult to achieve personal development and organizational development[5].

Creativity is an important element for anyone, and people are not trained to show it. Project-based learning requires students to practice problem-solving processes and creativity. Therefore, it is crucial to observe students' behaviors and attitudes in project-based learning classroom environments and determine if they acquire the necessary knowledge and skills[5]. This study attempted to examine the levels of problem-solving skills and creative attitudes of the students. Based on the study results, effective ways of improving students' competencies needed in project-based learning are suggested.

\subsection{Research Questions}

To answer the research questions, this study attempted to find out

1)What is the level of students' problem-solving skills and creative attitude?

2) Do students' problem-solving skills and creative attitudes differ depending on the variables such as gender, academic years, and academic areas?

3) Are students' problem-solving skills are related to creative attitudes?

\section{Literature Review}

Project-based learning is a teaching-learning method in which students learn to engage in projects to solve problems and achieve study goals under a given topic[5]. In project-based learning, learners create questions for themselves and explore the answers. Learners actively engage in design, problem-solving, decision making, and research activities to find the answers and produce outcomes[6][7]. Meanwhile, Moursund[8]defined project learning as a teaching-learning method that includes practical learning content and evaluation through collaboration and reflections. In this learning, a professor becomes a facilitator, and the learners usually work as a team. Therefore, collaboration with other learners and selfreflections are essential components in the learning process. Projects can proceed in both offline and online learning environments. There are online communication tools (e.g., google biz, zoom, etc.) that have been introduced to facilitate corporative learning. Since information can be easily collected, generated, and shared in online learning environments without having the time and special limitations, web-based project learning has also become an alternative for online lectures[5-8].

Prior research on project-based learning emphasizes that learners' characteristics influence team performance and cooperative activities affect goal achievement for successful learning. One of the characteristics is the creative mind. For learners' characteristics to positively influence learning, learners must believe that they will effectively contribute to completing their team tasks[6]. Problem-solving skills and creativity are other learners' characteristics that influence study achievement[9] have identified a static relationship between problem-solving and goal achievement. The study indicates that problem-solving skills influence goal achievement, and the performance of learning can be positive if learners properly managed their problem-solving abilities. Project-based learning is knowledge-based teamwork. In a knowledge-based work environment, not only should one leader be concentrated on the task, but the active participation of all the team members results in collective intelligence and creative products. While team members work as a group, they learn from each other and improve their creative ideas in complex and challenging situations[10].

Problem-solving is an emotional, cognitive, and behavioral process to understand a given situation and find solutions by analyzing the situations[11]. Problem-solving activities consist of personal problem solving, interpersonal problem solving, and social problem-solving. They are one of the essential and routine parts of our lives. Individuals attempt to discover the most effective and adaptive 
ways to cope with problem situations they encounter in their daily lives. The ability to handle problems in a systematic process after understanding a given situation and think of various alternatives and analyze what they will result in. The focus of problem-solving is to choose solutions that minimize adverse outcomes[10-12].

Researches[10-14] present that individuals with excellent problem-solving skills perform well in social interaction. In contrast, those with poor social problem-solving skills exhibit maladaptive selfconfidence and discomfort in psychological or emotional adaptation in interpersonal relationships. Therefore, students need to develop problem-solving skills in the curriculum. The process of problemsolving includes recognizing, discovering, and analyzing problems. Factors affecting problem-solving skills include critical thinking, self-directed learning, creativity, empathy, self-freedom, and emotional intelligence. Problem-based learning is an effective way of improving problem-solving skills[14-17]. In most cases, projects are given to experience the process of solving problems. Therefore, project-based learning would be based on the problems.

To develop the problems solving skills, students must have educational opportunities. The causes of poor problem-solving skills can be the lack of educational and training opportunities in the workplace and communication and cooperation. Along with problem-solving skills, creativity is one of the individual characteristics required in future society[17].

Creativity is one of the individuals' cognitive characteristics of developing new, effective, and efficient ideas to achieve the goals. Developing creativity means having active and positive attitudes in individuals' habits for an effective life. Creative people have passion and attachment to their work and enjoy their works. Creative tendencies are attitude characteristics required by individuals in the course of their creative thinking function. Creative tendencies are lifestyles and habits for developing creative ideas to achieve the goals[16]. Creative habits mean breaking away from the existing ways and exploring new things with interest and curiosity. People with creative habits actively engage in what they are doing and seek something new while avoiding stereotypes. People often are afraid of changing somethings in nature and are too tied to existing ways of thinking and ideas. Distinguishing from others also is one of the reluctant factors as well. People like to be buried in a group and try to follow what others have done[14-16].

Creative people are independent their thoughts and actions and curious about the world. Creative characters are courageous and curious. They think independently and act autonomously[14]. These internal characteristics are required when problem-solving situations encounter people. Creative problem-solving is a process of understanding unstructured problems, calculating ideas, and planning them to put them into practice. In this process, logical ideas and critical thinking work repeatedly and expand ideas in diverse aspects. Creative problem-solving skills are essential for students since most problems people face in daily lives are unstructured and require solving them creatively [14-17].

Society changes fast. Schools are deeply concerned about what and how to teach students in this changing society. Transferring knowledge and information would not be a role of schools anymore. Schools must offer students with practical learning experiences in problem-solving situations. Projectbased learning is one of the effective ways to bring about meaningful learning in the current revolutionary society.

\section{Research Method}

\subsection{Research Design}

A survey method was used to collect the data. A survey was conducted with the students who enrolled in the project-based classes. The researcher explained the study purposes to the participants and received permission from them for the data collection. The students' participation was voluntary, and the use of 
data was limited to the research purposes only. The project-based classes are divided into three classes based on the major areas, and one instructor taught all the classes with the same curriculum. The classes have been taught for 15 weeks. Two kinds of survey instruments were used for the study. One was a creative attitude survey, and the other was problem-solving skills survey. The creative attitude survey was conducted in the 4th week, and the problem-solving skills survey was conducted in the 8th week. The problem-solving ability instrument developed by Lee, Park, and Choi(2008)[17] was used. For creative attitudes, the instrument developed by Yoon(2005)[18] and Lim(1998)[19] was revised for research purposes. Both surveys were conducted online. The researcher uploaded the survey questionnaires on the research websites. The students downloaded and filled out the surveys and directly submitted them online.

\subsection{Class Design}

The project based-class was designed by combining a creative problem-solving and design thinking process. According to the creative problem-solving process, the class started with the problemrecognition process and spent a lot of time in problem definition finding real problems. The stage of empathy was adopted from the design thinking process and exercise to understand the user's or customers' need. In this class, small projects were given for each stage as a team. Individual activities were also given to learn the necessary knowledge and technology skills and put their contribution to team works. Activities for each stage is as shown the (figure 1) below.

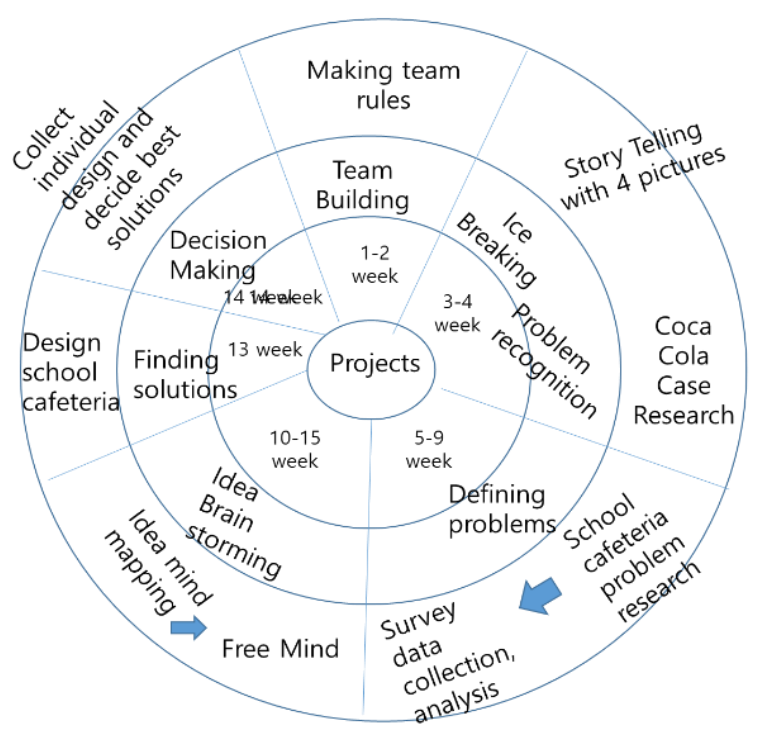

[Fig. 1] Class Design

\subsection{Participants}

A total of 144 students participated in this study. The participants enrolled in the project-based class in 2020. Three classes were offered according to the academic areas including nursing, engineering, and social science. Out of the total number participants, 104 were freshmen, and 40 were juniors. The freshman did not have any experience with project-based classes in the college yet. In addition, due to the social circumstances, they have been taking most of the classes online in the college. The junior participants had experiences with diverse class types, including project-based learning. Out of the total number of participants, there were 64 nursing majors, 19 social science majors, and 61 engineering 
major students. As per gender, ninety-five participants were male, and 49 participants were female. Detailed information about the participants is as shown.

[Table 1] Participants by Gender, Grade, and Academic Areas

\begin{tabular}{|c|c|c|c|c|c|c|c|}
\hline & & & & \multicolumn{3}{|c|}{ Academic Areas } & \multirow[b]{2}{*}{ Total } \\
\hline & & & & Nursing & Sicial Science & Engineering & \\
\hline \multirow[t]{4}{*}{ Gender } & \multirow[t]{2}{*}{ Male } & \multirow[t]{2}{*}{ Grade } & Freshman & 22 & 14 & 19 & 55 \\
\hline & & & Junior & 0 & 0 & 40 & 40 \\
\hline & \multirow[t]{2}{*}{ Female } & \multirow[t]{2}{*}{ Grade } & Freshman & 42 & 5 & 2 & 49 \\
\hline & & & Junior & 0 & 0 & 0 & 0 \\
\hline & & & Total & 64 & 19 & 61 & 144 \\
\hline
\end{tabular}

\subsection{Research Instruments}

Problem-solving skill surveys developed by Lee, Park, and Choi(2008)[17]. Creative attitudes surveys based on Yoon(2005)[18] and Lim(1998)[19]were used in the study. The problem-solving ability survey consists of 30 questions, and the reliability of the questionnaire are showed in [Table 2] The creative attitudes test consists of 13 questionnaires on independence, self-confidence, initiative, exploration, uniqueness, imagination, obsession, acceptability, patience, sensitivity, intuition, and sense of humor. The questionnaires were combined and revised from the existing creativity tests developed by Yoon(2005)[18] and Lim(1998)[19], and the Cronbach reliability test showed 0.77 for the questionnaire.

[Table 2] Survey Instruments

\begin{tabular}{|c|c|c|c|}
\hline \multirow{4}{*}{ Survey } & Categoty & Question number & Reliability \\
\hline \multirow{4}{*}{ Problem-solving skills } & Problem recognition & 5 & 0.79 \\
\cline { 2 - 4 } & Modifying information & 5 & 0.79 \\
\cline { 2 - 4 } & Analytic abilities & 5 & 0.81 \\
\cline { 2 - 4 } & Diverse thinking & 5 & 0.77 \\
\cline { 2 - 4 } & Decision making & 5 & 0.79 \\
\cline { 2 - 4 } & Planning ability & 5 & 0.81 \\
\hline Creative attitide & Creative attitude & 13 & 0.77 \\
\hline
\end{tabular}

\subsection{Data Analysis}

The data were analyzed using SPSS 26. Technical analysis such as means and standard deviations was used to look at the tendencies of the data. A T-test and ANOVA test were conducted to determine whether there are any differences in the results based on the variables such as gender and academic areas. In addition, Pearson's correlation test was conducted to see the correlations among problem-solving skills and creative attitudes. 


\section{Findings}

\subsection{Levels of Problem-solving skills and Creative Attitudes}

In order to determine the problem-solving skills, the problem-solving questionnaire was analyzed by category. According to the data analysis, the students' problem-solving skills were scored low $(\mathrm{M}=3.56)$. In particular, diverse thinking, the planning ability, and modifying information category were relatively lower than other categories. When analyzing the data by gender, there was a statistical difference in the diverse thinking $(\mathrm{p}<0.01)$ and decision making $(\mathrm{p}<0.01)$ areas. The data showed that female students $(M=3.4)$ showed stronger diverse thinking abilities than male students $(M=3.1)$. It also showed that females are better than males in prioritizing the important things in decision-making. When analyzing the data by academic areas, a statistical difference was found in the diverse thinking area $(\mathrm{p}<0.01)$. Nursing major students showed the highest mean score $(\mathrm{M}=3.3)$, and the social science major students showed the lowest mean scores $(\mathrm{M}=2.9)$.

[Table 3] Problem-solving Skills

\begin{tabular}{|c|c|c|}
\hline Categoty & Mean & S.D \\
\hline Problem recognition & 3.76 & 0.55 \\
\hline Modifying information & 3.55 & 0.58 \\
\hline Analytic abilities & 3.67 & 0.60 \\
\hline Diverse thinking & 3.21 & 0.54 \\
\hline Decision making & 3.67 & 0.65 \\
\hline Planning ability & 3.57 & 0.58 \\
\hline Total mean & 3.56 & 0.61 \\
\hline
\end{tabular}

[Table 4] T-test of the Diverse Thinking Area and Decision Making by Gender

\begin{tabular}{|c|c|c|c|}
\hline & T & F & P value \\
\hline Diverse Thinking & 4.544 & 1 & 0.00 \\
\hline Decision Making & 3.344 & 1 & 0.00 \\
\hline
\end{tabular}

[Table 5] Diverse Thinking Area by Academic Areas

\begin{tabular}{|c|c|c|c|}
\hline & $\mathrm{M}$ & $\mathrm{N}$ & S.D \\
\hline Nursing & 3.3937 & 64 & 0.45 \\
\hline $\begin{array}{c}\text { Social } \\
\text { Studies }\end{array}$ & 2.9895 & 19 & 0.52 \\
\hline Engineering & 3.0951 & 61 & 0.56 \\
\hline Total & 3.2139 & 144 & 0.53 \\
\hline
\end{tabular}

[Table 6] T-test of the Diverse Thinking Area by Academic Areas

\begin{tabular}{|c|c|c|c|}
\hline & $\mathrm{T}$ & $\mathrm{F}$ & P value \\
\hline Diverse Thinking & 3.883 & 2 & 0.00 \\
\hline
\end{tabular}




\subsection{Creative Attitudes}

When analyzing the students' creative attitudes, the data showed the respondents did not have many creative attitudes in their habit $(\mathrm{M}=3.39)$. In particular, they responded that they have many habitual elements in their behavior or attitude. When analyzing the data by gender and academic areas, there was not any statistical difference showed.

[Table 7] Creative Attitudes Test Results

\begin{tabular}{|c|l|l|l|}
\hline & \multicolumn{1}{|c|}{ Contents } & M & S.D \\
\hline 1 & I have a tremendous intellectual curiosity. & 3.32 & 0.89 \\
\hline 2 & I am interested in a wide range of fields. & 3.31 & 0.95 \\
\hline 3 & I have an intuition. & 3.34 & 0.87 \\
\hline 4 & I tend to focus on what I do. & 3.70 & 0.91 \\
\hline 5 & I have a distinct sense of purpose and a sense of participation in what I do. & 3.58 & 0.99 \\
\hline 6 & I am highly receptive and open to new experiences or information. & 3.43 & 0.98 \\
\hline 7 & I have few habitual elements in my behavior or attitude. & 2.87 & 1.01 \\
\hline 8 & $\begin{array}{l}\text { I am sometimes degenerate, and I am obsessed with ruminant thinking or alone } \\
\text { thoughts alone. }\end{array}$ & 3.19 & 0.89 \\
\hline 9 & I have an excellent ability to grasp and control my own emotions. & 3.42 & 0.94 \\
\hline 10 & $\begin{array}{l}\text { I sympathize with other people's position, and the criteria for judgment are } \\
\text { objective. }\end{array}$ & 3.71 & 0.90 \\
\hline 11 & I am confident in interpersonal relationships. & 3.39 & 1.03 \\
\hline 12 & I do not miss opportunities. & 3.23 & 0.84 \\
\hline 13 & I reject oppression or restraint from the outside world. & 3.37 & 0.90 \\
\hline & Average & 3.37 & 0.93 \\
\hline
\end{tabular}

\subsection{Relationships between Problem-solving Skills and Creative Attitude}

When analyzing the data using a person's relationship to see if there are any relationships among the variables, it showed that problem-solving skills are related with each other $(p<0.01)$ except for the modifying information, and divers thinking skills. The data analysis also showed relationships among the creative attitude and problem-solving skill areas except for modifying information area( $<<0.01)$. In detail, analytic abilities showed strong relationships with problem recognition and planning abilities. Planning skills and decision-making also showed strong relationships. Among the problem-solving areas, planning ability and analytical abilities showed the strongest relationships with creative attitudes.

[Table 8] Pearson's Correlations Test among the Variables $(\mathrm{n}=144)$

\begin{tabular}{|c|c|c|c|c|c|c|c|}
\hline $\mathrm{A}$ & $\begin{array}{c}\text { Problem } \\
\text { recognition }\end{array}$ & $\begin{array}{c}\text { Modifying } \\
\text { information }\end{array}$ & $\begin{array}{c}\text { Analytic } \\
\text { abilities }\end{array}$ & $\begin{array}{c}\text { Diverse } \\
\text { thinking }\end{array}$ & $\begin{array}{c}\text { Decision } \\
\text { making }\end{array}$ & $\begin{array}{c}\text { Planning } \\
\text { ability }\end{array}$ & $\begin{array}{c}\text { Creative } \\
\text { attitudes }\end{array}$ \\
\hline $\begin{array}{c}\text { Problem } \\
\text { recognition }\end{array}$ & & $.260^{* *}$ & $.507 * *$ & $.440 * *$ & $.590 * *$ & $.479 * *$ & $.514 * *$ \\
\hline $\begin{array}{c}\text { Modifying } \\
\text { information }\end{array}$ & & & $.318^{* *}$ & & $.334 * *$ & $.298^{* *}$ & \\
\hline Analytic abilities & & & & $.407 * *$ & $.702 * *$ & $.717 * *$ & $.557 * *$ \\
\hline Diverse thinking & & & & & .534 & .486 & $.462 * *$ \\
\hline
\end{tabular}




\begin{tabular}{|c|c|c|c|c|c|c|}
\hline Decision making & & & & & .608 & $.530 * *$ \\
\hline Planning ability & & & & & & $.596 * *$ \\
\hline $\begin{array}{c}\text { Creative } \\
\text { attitudes }\end{array}$ & & & & & & \\
\hline$* *$ Statistically significant: $P<0.001)$
\end{tabular}

\section{Conclusions}

\subsection{Study Results}

The results of the study showed that students have low levels of problem-solving skills and creative attitudes. In particular, diverse thinking, planning ability, and modifying information categories were relatively lower than other categories. In the case of diverse thinking and decision-making areas, there was a statistical difference by gender. The female students showed stronger diverse thinking and decision-making abilities than the male students. There was a statistical difference found in diverse thinking areas by academic areas as well. In addition, it appeared that problem-solving skills are correlated with each other. Analytic abilities showed strong relationships with problem recognition and planning abilities. Planning skills and decision-making also showed strong relationships. Creative attitudes' scores tend to be overly low, but problem-solving skills correlated with creative attitudes. Among the problem-solving areas, planning ability and analytic abilities showed the strongest relationships with creative attitudes.

\subsection{Suggestions}

The findings of this study shows that when problem-solving skills are improved, creative attitudes and creativity can also be improved since they are correlated. For improving students' achievement in their learning, strategies to improve problem-solving skills and creativity in instruction should be explored together. This study also showed that problem-solving skills and creative attitudes are not cultivated in a short period of time. Even though there have been many project-based activities during the semester for each design thinking stage, students did not show sufficient achievement in the target area of learning. Based on the study results, suggestions are made as follows;

First, teaching strategies for improving problem-solving skills and creative attitudes should be implemented as a long-term strategy in the diverse curriculum. Project-based learning classes should be offered in various learning fields in the curriculum, including the major areas and liberal arts areas. In general, project-based classes are provided in specific major areas such as engineering or art. However, regardless of the academic areas, activity-oriented classes should be offered. In that way, students would be able to make a habit of finding and solving problems with creative minds naturally without having any prejudice.

Second, more student-oriented classes should be developed and offered in the curriculum. A projectbased learning class is one type of student-oriented course. Including project-based learning, diverse types of instructional delivery methods, such as service learning and scenario-based learning, and problem-based learning should be implemented as a regular class type. Since society has been changing and there is information available everywhere, providing only lectures may not bring about meaningful learning. Students need hands-on experiences to learn authentic knowledge and problems. Students have to learn how to synthesize, analyze information, and decide on creative solutions rather than memorize the data in class. The data below is one example of class types that could be implemented in each college year. 
[Table 9] Types of Project-based Classes

\begin{tabular}{|c|c|c|}
\hline & Liberal arts area & Major area \\
\hline 1st year & $\begin{array}{c}\text { Design thinking class (Basic process about } \\
\text { problem-solving) }\end{array}$ & \\
\hline 2nd year & $\begin{array}{c}\text { Creative problem-solving class (Practice to find } \\
\text { creative solutions) }\end{array}$ & $\begin{array}{c}\text { Problem-based learning (Solving authentic problems from } \\
\text { the community) }\end{array}$ \\
\hline 3rd year & Service-learning- community linked & Capstone Design (I): Project-based class \\
\hline 4th year & Service-learning- Career linked & Capstone Design (II): Project-based class \\
\hline
\end{tabular}

Third, instructors need to prepare for the detailed instructional design with concrete instructional objectives and processes for the project-based class to be successful. In this study, the class was proceeded according to the creative problem solving and design thinking process based on the need of the class. Every academic field has differences in the way of achieving goals because the characteristics and nature of academic areas are different. For the best practice in class, the process of completing the projects should be modified by the instructors based on the need. Finding and defining problem stages are more important than other steps in specific fields, while actual outcomes are more important in other areas. Therefore, the instructors should design or modify a project-based learning process depending on the class topics. The table below shows a example of the learning process.

[Table 10] Sample of the Project-based Learning Process

\begin{tabular}{|c|c|c|c|c|c|c|c|c|}
\hline & \multicolumn{3}{|c|}{ Preparation } & & & & & \\
\hline Stage & $\begin{array}{c}\text { Need } \\
\text { analysis }\end{array}$ & $\begin{array}{c}\text { Instruction } \\
\text { al goals }\end{array}$ & $\begin{array}{c}\text { Assessmen } \\
\text { t method }\end{array}$ & $\begin{array}{c}\text { Problem } \\
\text { definition } \\
(1)\end{array}$ & $\begin{array}{c}\text { Team } \\
\text { work }\end{array}$ & $\begin{array}{c}\text { Problem } \\
\text { definition } \\
(2)\end{array}$ & $\begin{array}{c}\text { Find } \\
\text { solutions } \\
\text { Brainstormin } \\
\mathrm{g}\end{array}$ & $\begin{array}{c}\text { Present /evaluate } \\
\text { outcomes }\end{array}$ \\
\hline $\begin{array}{c}\text { Students } \\
\text { Context }\end{array}$ & $\begin{array}{c}\text { Learning } \\
\text { goals }\end{array}$ & $\begin{array}{c}\text { Students' } \\
\text { outcomes }\end{array}$ & $\begin{array}{c}\text { Finding a } \\
\text { project }\end{array}$ & $\begin{array}{c}\text { Team } \\
\text { building }\end{array}$ & $\begin{array}{c}\text { Data } \\
\text { collection } \\
\text { analysis }\end{array}$ & $\begin{array}{c}\text { Design } \\
\text { solutions }\end{array}$ & Layout outcomes \\
\hline
\end{tabular}

Creativity means change. While we remain unchanged and are immersed in our existing familiarity, students will be left behind. Change requires new learning and extra effort. In order to change, students must continue to encounter new ideas and acquire new knowledge and skills. In addition, students must freely express what they think and constantly ask, explore, and learn with curiosity and interest what they do not know. To achieve the study goals, students must be challenged with a little higher level of work than their ability to learn environments. It is also important to develop a habit of thinking from another point of view and from various angles, rather than just thinking on one side. When solving problems, students also learn not to jump to conclusions but learn how to assess the various possibilities. When considering the learning environments, project-based learning provides the most suitable learning conditions for the best practice. With students should train themselves to be active in curriculum and be positive and diverse in thinking. This study was conducted in a short period of time after the projectbased class was given. Therefore, for further research, it is necessary to examine the problem-solving skills and creative attitudes to see whether project-based classes help students improve their problemsolving abilities and creativity on a long term -based curriculum.

\section{References}

[1] Wikipedia, https://en.wikipedia.org/wiki/Problem_solving\#Definition, Mar 26 (2021) 
[2] E. Park, Study on the Relationship among Authenticity of Tasks, Flow, Academic Achievement and Learner Satisfaction in the Web-Based Project Learning Environment, Ewha Women's University, Master's Thesis, (2010)

[3] W. L. Lin, Y. W. Lien, The Different Role of Working Memory in Open-Ended Versus Closed-Ended Creative Problem Solving: A Dual-Process Theory Account, Creativity Research Journal, (2013), Vol.25, No.1, pp.85-96, DOI: $10.1080 / 10400419.2013 .752249$

[4] R. S. Shieh, W. Chang, Fostering Students Creative and Problem-solving Skills Through a Hands-on Activity, Journal of Baltic Science Education, (2014), Vol.13, No.5, pp.651-660.

[3] K. H. Tseng, C. C. Chang, S. J. Lou, P. S. Hsu, Using Creative Problem Solving to Promote Students' Performance of Concept Mapping, International Journal of Technology and Design Education, (2013), Vol.23, pp.1093-1109, DOI:10.1007/s10798-012-9230-8

[4] J. H. Hardy, A. M. Ness, J. Mecca, Outside the Box: Epistemic Curiosity as Predictor of Creative Problem Solving and Creative Performance, Personality and Individual Differences, (2017), Vol.104, pp.230-237.

[5] H. R. Chung, The Effects of Student Self-Generated Questioning Strategy on the Reading Comprehension and Creative Disposition, The Catholic University of Korea, Master's Thesis, (2012)

[6] W. S, Lee. S. H. Park, E. Y. Choi, Development of a Korean Problem-Solving Process Inventory for Adults, The Journal of Fundamentals of Nursing, (2008), Vol.15, No.4, pp.548-557, UCI : G704-001689.2008.15.4.009

[7] J. H. Lim, J. H. Jo, Effects of Reflective Journal Writing and the Feedback Provided by Teacher on Learning Achievement and Attitude in Web-Based Project Learning, Elementary Education Journal, (2007), Vol.14, No.2, pp.137-160.

[8] D. Moursund, Project-based Learning Using Information Technology,( first edition), International Society for Technology in Education, (1999), pp.158,

[9] Y. J. Joo, D, D, Kim, The Structural Relationship among Metacognition, Interactions, Problem Solving Ability and Achievement in Gifted Students Through the 3P Model, Journal of Gifted/Talented Education, (2015), Vol.25, No.1, pp.166-177, UCI : G704-001841.2015.25.1.005

[10] S. O. Hwang, The effect of shared leadership on team creativity in R\&D project team, Dankook University, Master's Thesis, (2020)

[11] M. S. Jeon, The Influence of Problem-Solving Programs on the Competency of University Students, Studies on Korean Youth Activity, (2019), Vol.5, No.4, pp.91-109, DOI : 10.36697/skya.2019.5.4.91

[12] H. E. Lee, Effects of collaborative context-based maker education environments on flow, creative personality, and sociality among middle school students, Konkook University, Doctoral Dissertation, (2020)

[13] H. S. Park, The relationship between problem-solving ability, self-efficacy for group work, co-regulation, Ewha Women's University, Master's Thesis, (2015)

[14] Y. S Kim. International comparison of Korean adults competency: Focusing on problem solving skill, Research of Social Science, (2019), Vol.45, No.3, pp.107-123, http://dx.doi.org/10.15820/khjss.2019.45.3.005

[15] S. J. Lee. Y. H. Kim, A New Perspective on Opportunity Capturing of Entrepreneurs: Focusing on Problem Recognition and Problem Solving Capabilities, Journal of Entrepreneurship and Venture Studies, (2019), Vol.22, No.2, pp.1-16.

[16] J. S. Han, The Effects of Project-Based Learning AI classes on Creative Problem Solving Ability, Korea Teacher's College, Master's Thesis, (2020)

[17] W. S. Lee, S. H. Park, E. Y. Choi, Development of a Korean Problem-Solving Process Inventory for Adults, Journal of Korean Academy of Fundamentals of Nursing, (2008), Vol.15, No.4, pp.548-557.

[18] M. H. Yoon, Development of Creativity Personality Tests for Children, Asian Journal of Education, (2005), Vol.6, No.4, pp.33-51, UCI : G704-000733.2005.6.4.009

[19] H. S. Lim, A Study on the Validation of Creativity Measurement Tools, Seoul University, Master's Thesis, (1989) 